\title{
Hva er faglig forsvarlig hjemmesykepleie?
}

\section{Forfattere}

\author{
Siri Tønnessen \\ Førsteamanuensis \\ Avdeling for sykepleievitenskap, Høgskolen i Sørøst-Norge \\ Per Nortvedt \\ Professor \\ Senter for medisinsk etikk, Universitetet i Oslo
}

Eldre

Forsvarlighet

Hjemmesykepleie

Omsorg

Sykepleien Forskning 2012 7(3)(280-285)

DOI: https://doi.org/10.4220/sykepleienf.2012.0134

\section{Sammendrag}

Bakgrunn: I dag er minstenormen for hva som er nødvendige og forsvarlige sykepleietjenester uklar. Særlig innen hjemmesykepleie synes det å være stor avstand mellom hva som er pasientenes behov for tjenester og de tjenestene pasientene faktisk får ivaretatt.

Hensikt: hensikten med artikkelen er å klargjøres innholdet i begrepet om sykepleiefaglige forsvarlige pleie- og omsorgstjenester.

Metode: Basert på funn fra en tidligere studie om sykepleiernes prioriteringer i hjemmesykepleien og pasientenes opplevelse av tjenesten presenteres tre krav til hva vi mener akseptable sykepleietjenester må kunne tilfredsstille: 1. Pasientene skal få hjelp til å få dekket grunnleggende behov. 2. Tildelte tjenester skal ivaretas i tilstrekkelig grad og i tråd med faglige normer. 3. Pasientens behov skal ivaretas slik at grunnleggende verdier i samhandlingen mellom sykepleier og pasient ikke krenkes.

Resultater: De tre kravene beskrives og diskuteres i forhold til relevant forskning på området. Kravene er kriterier på individnivå og begrunnes i sykepleiefaglige normer, verdier og kunnskaper samt hjemmesykepleiens hensikt og ansvar. 
Konklusjon: Forsvarlighetskravet til akseptable sykepleietjenester må være i tråd med sykepleiefagets grunnlag og hensikten med tjenesten. Sykepleierne har et eget ansvar for å innholdsbestemme hva som er forsvarlige tjenester og omsorgsfull hjelp i hjemmesykepleien.

Sykepleierne i hjemmesykepleien skal ivareta pasientenes behov for pleie- og omsorgstjenester på en faglig forsvarlig og omsorgsfull måte (1-3). Det er imidlertid uklart hva som anses som minstenormen for nødvendige og forsvarlige pleie- og omsorgstjenester (4-6). Det mangler en grundig diskusjon av hvilke pleie- og omsorgstjenester som skal inngå i det offentliges tilbud, og hva som skal anses som en faglig akseptabel minstenorm (7-10). Hensikten med denne artikkelen er å avklare hva det vil si at tjenestene i hjemmesykepleien skal være faglig forsvarlig og at hjelpen som ytes skal være omsorgsfull.

Kravene til forsvarlige tjenester som presenteres i det følgende handler om kriterier i relasjonen mellom sykepleier og pasient. Kriteriene bygger på faglige normer i tråd med sykepleiens grunnlag og hjemmesykepleiens hensikt og ansvar.

\section{Tre krav}

Det første forsvarlighetskravet vi vil skissere innholdsbestemmer hvilke pleie- og omsorgstjenester sykepleierne i hjemmesykepleien skal ivareta. I det andre kravet klargjør vi hva omsorgsfull og forsvarlig helsehjelp innebærer i forhold til disse tjenestene. Det tredje forsvarlighetskravet handler om hvordan verdier bør komme til uttrykk i sykepleierens væremåte i møtet med pasientene.

\section{Pasientene skal få hjelp til å få dekket grunnleggende behov}


Dette kravet handler om hvilke pleie- og omsorgstjenester pasientene skal få vurdert og ivaretatt av sykepleierne og beskriver de grunnleggende behovene som vi mener må regnes som nødvendige helsetjenester i hjemmesykepleien. I tråd med pleie- og omsorgstjenestenes formål, innhold og oppgaver beskriver Forskrift om kvalitet i pleie og omsorgstjenestene (heretter omtalt som Kvalitetsforskriften) hvilke grunnleggende behov pasientene skal få ivaretatt fra kommunehelsetjenesten (11). Kvalitetsforskriften gir ikke brukerne rett på bestemte tjenester, men kommunene «pålegges å utarbeide prosedyrer som sikrer at brukerne får ivaretatt grunnleggende behov på en god måte» (ibid.).

Grunnleggende behov pasientene skal få ivaretatt i hjemmesykepleien er:

- Oppleve respekt, forutsigbarhet og trygghet $\mathrm{i}$ forhold til tjenestetilbudet

- Selvstendighet og styring av eget liv

- Fysiologiske behov som tilstrekkelig næring, variert og helsefremmende kosthold og rimelig valgfrihet i forhold til mat

- Sosiale behov som mulighet for samvær, sosial kontakt og unødig sengeopphold

- Mulighet for ro og skjermet privatliv

- Få ivaretatt personlig hygiene og naturlige funksjoner

- Mulighet til selv å ivareta egenomsorg

- En verdig livsavslutning i trygge og rolige omgivelser

- Nødvendig medisinsk undersøkelse og behandling, rehabilitering, pleie og omsorg tilpasset den enkeltes tilstand

- Nødvendig tannbehandling og ivaretatt munnhygiene 
- Tilbud tilrettelagt for personer med demens og andre som selv har vanskelig for å formulere sine behov

- Tilpasset hjelp ved måltider og nok tid og ro til å spise

- Tilpasset hjelp ved av- og påkledning

- Tilbud om varierte og tilpassete aktiviteter (11).

De tjenestene vi har listet opp her samsvarer i stor grad med det som i sykepleiefaget regnes som grunnleggende sykepleie overfor pasienter (12), og som Henderson beskriver som sykepleiens grunnprinsipper (13). Det innebærer at nødvendige pleie- og omsorgstjenester går ut over det å dekke fysiologiske, medisinske og psykososiale behov. Forsvarlige tjenester i hjemmesykepleie handler også om at verdier må ivaretas, som at pasienten opplever respekt, trygghet, forutsigbarhet, selvstendighet, verdighet og muligheten til egenomsorg (ibid.). Uten disse verdiene er det ikke samsvar mellom innholdet $\mathrm{i}$ kvalitetsforskriften og sykepleiefaglige krav til grunnleggende omsorgstjenester $(12,13)$.

\section{Hvilke behov ivaretas?}

Forskning viser at pasientene i hjemmesykepleien får mat, medisiner, hjelp til personlig hygiene (ikke munnstell), toalettbesøk, påkledning og avkledning. Disse tjenestene blir ofte opplevd som en minimumsstandard for pleie- og omsorgstjenester (10). Sykepleiernes mulighet til å vurdere og ivareta pasientenes behov ut fra en helhetlig tilnærming er imidlertid begrenset (10). Psykososiale og åndelige behov vurderes ikke som en del av hjemmesykepleiens tjenester. Pasientene tilbys få aktiviteter og munnstell ivaretas sjeldent. Tjenester rasjoneres daglig, pasientbehov blir oversett og muligheten til å ta individuelle hensyn er begrenset $(7,9,10,14)$. 
Behovene hjemmesykepleien ivaretar i dag handler derfor kun om å opprettholde basale livsfunksjoner. Skal tjenestene være i tråd med grunnleggende sykepleie må psykososiale og åndelige/eksistensielle behov også vurderes og ivaretas samt at pasientene må få tilbud om aktiviteter og få ivaretatt munnhygiene $(12,13)$. Videre må en akseptabel minstenorm for omsorgsfull hjelp innebære at sykepleierne kan ta mer helhetlige og individuelle hensyn i situasjonen slik at verdier som respekt og trygghet kan ivaretas $(10,11)$.

Sykepleierforbundets minstekrav til nødvendige tjenester er at pasientene får dekket grunnleggende behov som ernæring, søvn og hygiene (15). Dette minstekravet regnes ikke som tilstrekkelig for å kunne si at tjenestene dekker grunnleggende behov eller er sykepleiefaglig forsvarlig. Kravet vi fremmer synliggjør at skal tjenestene i hjemmesykepleien være sykepleiefaglig forsvarlig, må pasientene få vurdert og ivaretatt nødvendige behov i tråd med Kvalitetsforskriften (11). Slik er det ikke i dag.

\section{Tildelte pleie- og omsorgstjenester skal ivaretas $i$ tilstrekkelig grad slik at nødvendige behov dekkes $i$ tråd med faglige normer.}

Dette kravet handler om at kvaliteten på tjenestene pasienten trenger å få dekket, må være faglig tilfredsstillende. Kravet er en utdyping av det rettslige kravet til forsvarlighet med henblikk på innholdet i sykepleietjenesten.

\section{Faglige kriterier}


Det hører til sykepleiernes generelle basiskunnskaper å kunne sette i gang tiltak for å ivareta pasientenes behov når ulike funksjoner svikter $(12,13)$.

Eksempelvis vet en sykepleier hva som er tilstrekkelig næring, hvilke tegn som viser seg når pasienten er feilog/eller underernært, og hvilke tiltak som er nødvendige å sette i gang. En sykepleier vet hvordan de kan tilrettelegge for at pasienter skal kunne ivareta personlig hygiene selv, og hvordan pasienten svekkes hvis sykepleieren "gjør for” pasienten. En sykepleier vet betydningen av tid og rom for å kunne gå inn i vanskelige samtaler, og skal ha kunnskap og ferdigheter til å hjelpe både familien og den døende slik at det blir en verdig livsavslutning. Hjemmesykepleie handler nettopp om å hjelpe pasienter med å ivareta grunnleggende funksjoner og å yte omsorg når pasienter ikke klarer det selv. Sykepleierne kan vurdere om pleie- og omsorgstjenestene i hjemmesykepleien er av en slik karakter at de kan beskrives som kvalitetsmessig tilfredsstillende, og dermed forsvarlige $(9,12,13)$.

\section{Omsorgsfull hjelp?}


Vår egen og andres forskning viser at tjenestene i hjemmesykepleien ikke ivaretar pasientenes behov godt nok (9, 16-19). Sykepleierne beskriver at pasientene opplever et sprik mellom det de har behov for, og det de får av tjenester. Et eksempel på dette kan være at pasienten av innsparingshensyn får hurtigmiddag som varmes i mikrobølgeovnen, og at de må spise måltidene alene. Tjenestene som tilbys kan medføre ensidig kost og innebære at pasientene ikke får i seg nok næringsstoffer. Mange pasienter trenger også noen som kan påse at de faktisk spiser maten. I et teknisk perspektiv har kanskje pasienten fått tilgang til nok kalorier, men maten kan være suboptimal og tar eventuelt ikke hensyn til pasientens individuelle behov. Slik kan denne ytelsen neppe betegnes som faglig god eller omsorgsfull. En omsorgsfull ivaretakelse av pasientenes behov må bygge på at tjenestene ytes i tråd med relevant fagkunnskap og er tilpasset den enkeltes situasjon. Pasientene trenger både «tilstrekkelig næring, variert og helsefremmende kosthold» (11). Man kan imidlertid diskutere hva som er «rimelig valgfrihet i forhold til mat» (ibid.).

\section{Forsinkete tjenester}

Både pasienter og sykepleiere beskriver at pasientene ikke får tjenester til avtalt tid $(7,14)$. Pasienter kan måtte vente i opp til flere timer på morgenstell eller for å komme seg på toalettet. Så lang ventetid bryter med faglige normer, fordi det er både respektløst og uverdig. Vår forskning viser at forsvarlighetsnormen i hjemmesykepleien i stor grad knyttes til en medisinsk minstenorm om helsehjelp som er påtrengende nødvendig $(7,10,14)$. Sykepleierne i hjemmesykepleien kan ikke sette grensene for forsvarlige tjenester ved fare for liv og helse. Da ivaretas ikke pasientenes omsorgsbehov og faglige verdier trues (9). Da ivaretas ikke kravet til faglig forsvarlighet.

\section{Organisering styrer faget}


Sykepleiere beskriver at ansvaret de har overfor pasienter er å yte de tjenestene som er beskrevet $\mathrm{i}$ enkeltvedtaket pasienten får når han/hun innvilges tjenester fra hjemmesykepleien (14). Enkeltvedtak på tjenester fra hjemmesykepleien er lovpålagt og derfor juridisk bindende (20, 21). Myndighetenes hensikt med å innføre enkeltvedtak var å styrke pasientenes rettigheter for å sikre tilfredsstillende tjenester. Forskning viser at enkeltvedtakene begrenser sykepleierne i å imøtekomme pasientens behov i situasjonen (10). Skal tjenesten være omsorgsfull må sykepleieren ha mulighet til å ivareta pasientens individuelle behov her og nå, og ikke være styrt av vedtak gjort en tid tilbake og av andre enn de som yter tjenester i pasientenes hjem. Flere argumenterer for at en oppsplitting av helhetlige tjenester $\mathrm{i}$ isolerte enkeltvedtak er grunnleggende i strid med sykepleiens ethos $(22,23)$.

\section{Pasientens behov for tjenester skal ivaretas slik at grunnleggende verdier $i$ samhandlingen mellom sykepleier og pasient ikke krenkes.}

Dette kravet handler om måten sykepleierne ivaretar pasienten på i situasjonen. Kravet innebærer at sykepleierne skal yte omsorgsfull hjelp slik at pasientenes integritet ivaretas (2, 6, 24). Skal tjenestene være forsvarlig må derfor relasjonelle verdier som respekt og selvstendighet ivaretas slik at pasientene ikke krenkes $(25,26)$. Det innebærer at grunnleggende behov må dekkes på en slik måte at pasientene opplever seg sett og ivaretatt i situasjonen.

\section{Respekt og krenkelser}


Undersøkelser viser at pasientene opplever krenkelser i omsorgssituasjonen (27-31) og at hjemmesykepleie er omsorg på det administrative systemets premisser ( 7 , 28, 31). Pasientenes selvstendighet krenkes når hjemmesykepleien er forsinket og tjenesten er uforutsigbar (7, 28-30). Hjelpen er ikke omsorgsfull når pasientene beskriver at sykepleierne ikke har tid til å ta individuelle hensyn og være fleksible. Pasientene kan ikke få legge seg når de vil eller komme på toalettet når de har behov for det. Respekt og medmenneskelighet er grunnleggende i all omsorg og særlig viktig når pasienten er syk og trenger profesjonell ivaretakelse $(32,33)$. Skal tjenestene være sykepleiefaglig forsvarlig må derfor mellommenneskelige verdier ivaretas i situasjonen. Først da er hjelpen omsorgsfull.

\section{Pasienten vil bo hjemme}

Til tross for krenkelser tyder mye på at pasientene vil bo hjemme. Det å bo hjemme medfører at de kan bevare sine interesser, ivareta sosiale roller og opprettholde sitt sosiale nettverk i kjente omgivelser. Å flytte på institusjon vil medføre nok et tap, og øke opplevelsen av å være avhengig og sårbar. Tjenestene fra hjemmesykepleien gir pasientene større selvstendighet, og dermed ivaretas selvfølelsen. På den annen side er det noe uverdig ved omsorgssituasjonene i hjemmesykepleien; For å kunne bo hjemme er pasientene villig til å tåle uforutsigbare tjenester, mange hjelpere, å planlegge dagene ut fra hjemmesykepleiens organisering, mikromat, spise alene, å legge seg før de ønsker det, fordi alternativet er institusjon, og ikke en tilfredsstillende tjeneste (9).

\section{Mangelfulle tjenester}


Overraskende mange pasienter beskriver

hjemmesykepleien i positive ordelag, og sier at de er fornøyde (7). De som jobber i hjemmesykepleien blir beskrevet som «engler», blide, søte, oppmerksomme og imøtekommende i situasjonen. På den ene siden kan man si at pasienten blir respektert, fordi de ansatte i hjemmesykepleien tar hensyn og er omsorgsfulle. Skylden for et dårlig tilbud blir lagt på systemet og ikke på helsepersonell. På den annen side må et faktisk minstemål av tjenester ytes, skal tjenesten være faglig forsvarlig. Slik er det ikke i dag. Selv fornøyde pasienter sier at tjenesten ikke er tilfredsstillende (9). Det er ikke godt nok, skal tjenesten være forsvarlig og hjelpen omsorgsfull.

\section{Konklusjon}

I denne artikkelen har vi argumentert for at kriterier for forsvarlige tjenester og omsorgsfull hjelp i hjemmesykepleien må utvides i tråd med sykepleiens grunnlag og hensikten med tjenestene. Tre krav til forsvarlige tjenester og omsorgsfull hjelp er framsatt. Særlig er kravet om omsorgsfull hjelp viktig i sykepleie, og må spesifiseres og tas alvorlig. Det kan innvendes at en utvidelse av forsvarlighetskravet vil bety at kravet til bemanning øker og at kostnadene vil øke. Det å utvide kravet på denne måten kan også gjøre det vanskeligere å spesifisere tjenestene. På den annen side er det helt nødvendig å tilpasse et forsvarlighetskrav i hjemmesykepleien til de normer, verdier og kunnskaper som gjelder for tjenesten og sykepleiefaget. Innholdet i grunnleggende sykepleietjenester er konkret og utfyllende beskrevet i sykepleielitteratur. Skal pasientene få dekket grunnleggende behov er det nødvendig at sykepleierne selv tar ansvar for å utvikle forsvarlighetskriterier ved å formulere verdier, prinsipper og krav slik vi har gjort her.

\section{Referanser}


1. Lov om helsepersonell. 2 juli 1999; nr.4. [Helsepersonelloven]. Tilgjengelig fra:

http://www.lovdata.com/cgiwift/wiftloksok? sys=1\&felttitt\&emnehelsepe.... (Nedlastet: 06.01 .2012 )

2. Helse- og omsorgsdepartementet og Arbeids- og sosialdepartementet. NOU 2004-18. Helhet og plan i sosial- og helsetjenestene: samordning og samhandling i kommunale sosial- og helsetjenester. Helse- og omsorgsdepartementet og Arbeids- og sosialdepartementet. Oslo. 2004.

3. Helse- og omsorgsdepartementet. St.meld.nr. 47 (2008-2009) Samhandlingsreformen. Helse- og omsorgsdepartementet. Oslo. 2009.

4. Halvorsen M. «Nødvendig helsehjelp» som redskap for prioriteringer. Lov og Rett. 2004;143-56.

5. Kjønstad A. Helserett - pasienters og helsearbeideres rettsstilling. 1 ed. Gyldendal Norsk Forlag, Oslo. 2005.

6. Molven O. Kravet til helsepersonell og virksomheter i helsetjenesten om forsvarlighet. Lov og Rett. 2009;48:3-26.

7. Tønnessen S, Førde R, Nortvedt P. Pasientenes beskrivelser av hjemmesykepleien når ressursene er begrenset, Omsorg på andres premisser. Nordisk Tidsskrift for Helseforskning. 2009;5:57-71.

8. Sosial- og helsedepartementet. NOU 1997-18. Prioritering på ny: gjennomgang av retningslinjer for prioriteringer innen norsk helsetjeneste. Sosial- og helsedepartementet. Oslo. 1997. 
9. Tønnessen S. The challenge to provide sound and diligent care - A qualitative study of nurses' decisions about prioritization and patients' experiences of the home nursing service. Doktorgradsavhandling. University of Oslo, Oslo. 2011.

10. Tønnessen S, Nortvedt P, Førde R. Rationing home-based nursing care - Professional ethical implications. Nursing Ethics. 2011;18:386-96.

11. Forskrift om kvalitet i pleie og omsorgstjenestene for tjenesteyting etter lov av 19. november $1982 \mathrm{nr} .66$ om helsetjenesten i kommunene og etter lov av 13. desember $1991 \mathrm{nr} .81 \mathrm{om}$ sosiale tjenester m.v. 27 juni 2003; nr. 792. Tilgjengelig fra: http://lovdata.no/cgiwift/wiftldles?

doc=/app/gratis/www/docroot/for/sf/ho/ho-200306270792.html\&emneKVALITET*\%20 \%2b\%20I*\%20 \%2b\%20PLEIE*\%20 \%2b\%20OG*\%20 \%2b\%20OMSORGSTJENEST*\&\&. (Nedlastet: 06.01.2012)

12. Kristoffersen NJ, Nortvedt F, Skaug E-A. Grunnleggende sykepleie Bind 1,2. og 3. Gyldendal akademisk, Oslo. 2011.

13. Henderson V. Basic principles of nursing care. International Council of Nursing. Geneva, 1997.

14. Tønnessen S, Førde R, Nortvedt P. Fair nursing care when resources are limited: The role of patients and family members in norwegian home-based services. Policy, Politics, \& Nursing Practice. 2009;10:276-84.

15. Norsk Sykepleierforbund. Det du bør vite om Faglig Forsvarlighet. Norsk Sykepleierforbund. Oslo, 2008. 
16. Nortvedt P, Pedersen R, Grothe KH, Nordhaug M, Kirkevold M, Slettebo A, et al. Clinical prioritisations of healthcare for the aged - Professional roles. J Med Ethics. 2008;34:332-5.

17. Sørbye LW. Frail homebound elderly: basic nursing challenges of home care. Doctoral Thesis. University of Tromsø. Tromsø. 2008.

18. Hofseth C, Norvoll R. Kommunehelsetjenesten gamle og nye utfordringer: en studie av sykepleietjenesten i sykehjem og hjemmesykepleien. Sintef. Unimed, Trondheim. 2003.

19. Rønning R. Omsorg som vare?: kampen om omsorgens sjel i norske kommuner. Gyldendal akademisk, Oslo. 2004.

20. Lov om behandlingsmåten i forvaltningssaker 2 oktober 1967. [Forvaltningsloven]. Tilgjengelig fra: http://lovdata.no/cgi-wift/wiftldles? doc=/app/gratis/www/docroot/all/nl-19670210000.html\&emneFORVALTNINGSLOV*\&\&. (Nedlastet: 06.01.2012)

21. Lov om kommunale helse- og omsorgstjenester m.m. 24 juni 2011; nr. 30 [Helse- og omsorgstjenesteloven]. Tilgjengelig fra: http://lovdata.no/cgi-wift/wiftldles? doc=/app/gratis/www/docroot/all/nl-20110624030.html\&emneKOMMUNALE*\%20 \%2b\%20HELSE*\%20 \%2b\%20OG*\%20 \%2b\%20OMSORGSTJENESTER*\&\&. (Nedlastet: 06.01.2012).

22. Martinsen K, Eriksson K. Å se og å innse: om ulike former for evidens. Akribe, Oslo. 2009.

23. Vetlesen AJ, Henriksen J-O. Moralens sjanser i markedets tidsalder. Om kulturelle forutsetninger for moral. Gyldendal Akademisk, Oslo. 2007. 
24. Molven O. Helse og Jus, En innføring for

helsepersonell. 6 ed. Gyldendal Norsk Forlag AS,

Oslo. 2009.

25. Braut GS. Fagleg forsvarleg verksemd handlar om gode prosessar. Tidsskrift for Den norske legeforening. 2008:19.

26. Braut GS, Vist jr. J. Faglig forsvarlighet- garanti og grense. In: Torgauten T-I. (red.). Utviklingshemming og tros- og livssynsutøvelse Rettigheter og tilrettelegging. Universitetsforlaget, Oslo. 2010

27. Lillestø B. Når omsorgen oppleves krenkende. En studie av hvordan mennesker med fysiske funksjonehemminger opplever sitt forhold til hjemmetjenesten. Nordlandsforskning. NF- rapport nr. 22/98. Bodø, 1998.

28. Ellefsen B. Dependency as disadvantage Patients' experiences. Scandinavian Journal of Caring Sciences. 2002;16:157-64.

29. Digre E. Ivaretakelse av grunnleggende behov: En intervjuundersøkelse av brukerens syn på kvalitet og deres behov for pleie og omsorg. Høgskolen i Buskerud, Drammen. 2001.

30. Haug HK. $\AA$ venne seg til - En studie om de eldres erfaringer med hjemmesykepleien. Universitetet i

Oslo. Oslo. 2004.

31. Sørum BM. Å få være med å bestemme - En studie om hjemmeboende kvinners opplevelse av trivsel når de er avhengige av hjemmesykepleie. Universitetet i Oslo, Oslo. 2004.

32. Nortvedt P. Sykepleiens grunnlag: Historie, fag og etikk. Universitetsforlaget, Oslo. 2008.

33. Martinsen K. Fra Marx til Løgstrup: Om etikk og sanselighet i sykepleien. TANO, Oslo. 1993. 
